\title{
A Rare Case of Eosinophilic Cholecystitis Presenting in a Patient with Thalassemia Intermedia; a Case Report
}

\author{
Mohammad Ranaee $^{1,2}$ id , Maryam Khosravi $^{3}$ id , Zeinab Vosough $^{1,2^{*}}$ (D) \\ 1. Cancer Research Center, School of Medicine, Babol University of Medical Sciences, Babol, Iran \\ 2. Dept. of Pathology, School of Medicine, Babol University of Medical Sciences, Babol, Iran \\ 3. Clinical Research Development, Unite of Rouhani Hospital, Babol University of Medical Sciences, Babol, Iran
}

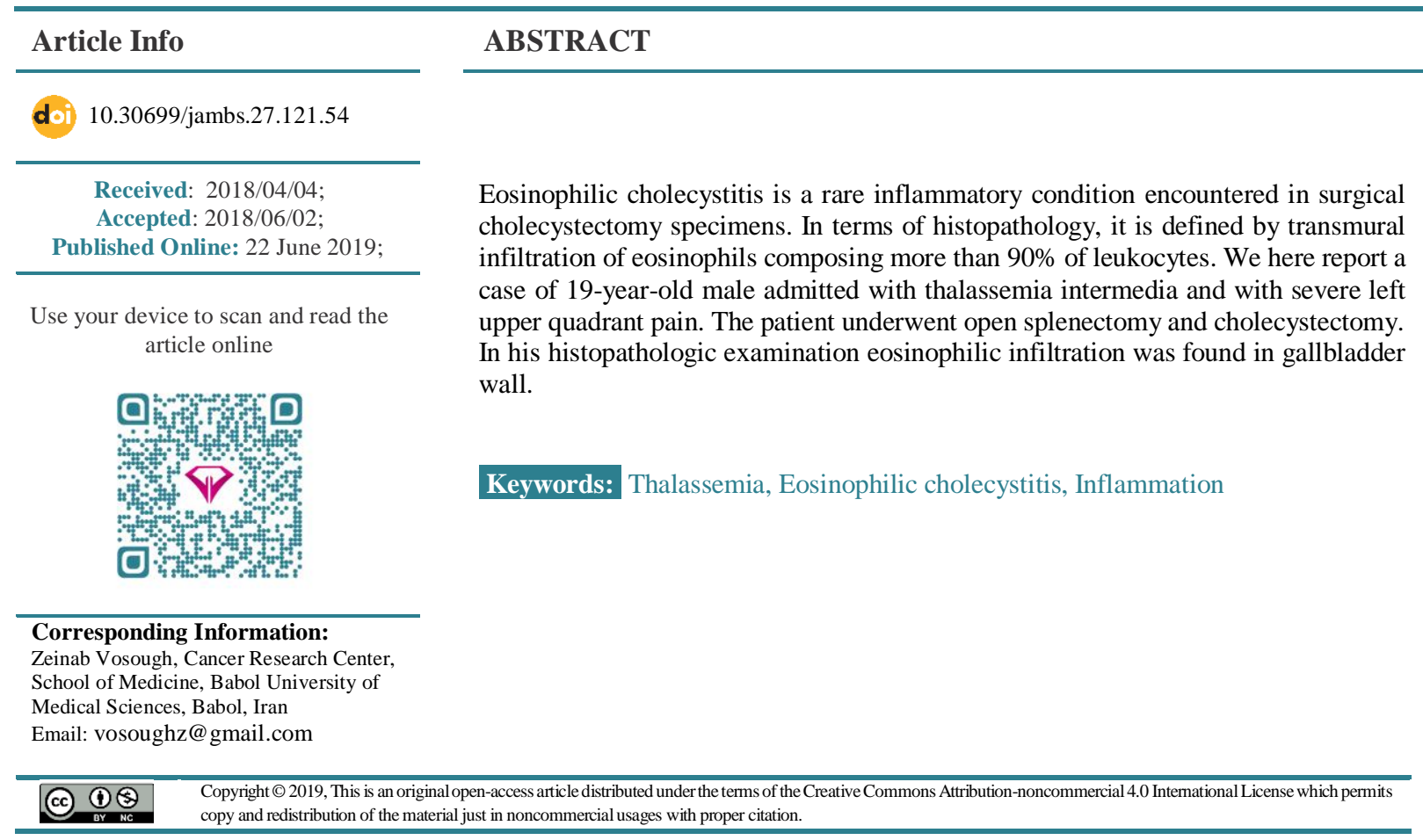

\section{Introduction}

Eosinophilic cholecystitis (EC) is a rare inflammatory condition of the gallbladder that was first mentioned in a study in 1949 (1). The prevalence of EC was reported from $0.1 \%$ to $6.4 \%$. (2-4). Histologically, EC is confirmed when the transmural infiltration of the eosinophils composes more than $90 \%$ of leukocytes (2). The etiology of EC is obscure but numerous theories have been proposed including allergic reaction, parasitic infestation, eosinophilic gastroenteritis, hypereosinophilic syndrome (the eosinophils infiltrate tissues such as the brain, heart, lung, liver, and gallbladder) and the local reaction to gallstones (5-7). The diagnosis of eosinophilic cholecystitis is based on histopathologic findings because it has no specific clinical or laboratory feature. The main treatment in cases of typical cholecystitis is cholecystectomy. If there are any associated conditions treatment should also be followed.

\section{Case Report}

The patient was a 19-year-old male with a case of thalassemia intermedia who was admitted with severe left upper quadrant pain and was suspected for splenic crisis. At the time of admission, the patient's vital signs were $37.6^{\circ} \mathrm{C}$ temperature, 78 beats per minute heart rate, 20 breaths per minute respiration rate and $128 / 75 \mathrm{~mm} \mathrm{Hg}$ blood pressure.

Past medical history revealed thalassemia intermedia with a history of right upper abdomen pain for the past 6 months and a loss of appetite due to chronic cholecystitis. An allergy to fava beans, known as favism, was also apparent. Medications consisted of folic acid tablets, periodic pneumococcal vaccinations, and at rare times a blood transfusion. The patient had not recently received courses of antibiotics or steroids and he denied any illicit drug or herbal supplement usage. He did not drink alcohol or smoke.

A physical examination was pertinent for his left upper quadrant tenderness and the enlargement of his spleen (Palpable $3 \mathrm{~cm}$ below the costal margin). Right upper quadrant tenderness was not detected during the examination and the Murphy sign was also not identified.

The initial laboratory tests are outlined in Table 1, which notes a mildly decreased $\mathrm{Hb}$ level, no eosinophilia, and an elevated bilirubin level, which results in a hemolytic anemia diagnosis. An ultrasound \& CT scan of 
the abdomen demonstrated splenomegaly, increased spleen parenchymal echogenicity, and multiple gallstones.

The patient rejected additional imaging studies, such as Magnetic Resonance Imaging (MRI), due to his claustrophobia.

The patient was prescribed cephalosporin and penicillin during his hospital stay and underwent an open splenectomy due to his splenic crisis and a cholecystectomy due to his chronic cholecystitis. No intra or post- operative complications were encountered. The patient was discharged two days after surgery.
Histopathology findings showed a congested splenic tissue (Figure 1B) and eosinophilic cholecystitis (Figure 1A). On gross examination of specimen, the gallbladder was pear-shaped and measured $12 \times 7 \times 4 \mathrm{~cm}$ and on opening gallbladder the maximal wall thickness was 0.3 $\mathrm{cm}$. The internal surface had a velvety green mucosa which contained multiple stones with the maximum measurement of $1.5 \mathrm{~cm}$. Microscopic views revealed a marked eosinophilic infiltration with few lymphoplasma cell infiltrations, which confirmed the diagnosis of EC. There were no evidence of epithelial dysplasia, parasitic infestation, or identified malignancy.

Table 1. Laboratory test results

\begin{tabular}{|c|c|c|c|}
\hline Blood test & Pre-operation Results & Post-operation Results & Normal Reference Interval \\
\hline WBC & $7.4 \times 10^{9} / \mathrm{L}$ & $\begin{array}{c}24.1 \times 10^{9} / \mathrm{L} \\
\text { Neutrophil } 88 \% \\
\text { Lymphocyte 6\% } \\
\text { Eosinophil 3\% } \\
\text { Monocyte 3\% }\end{array}$ & $4-11 \times 10^{9} / \mathrm{L}$ \\
\hline $\mathrm{RBC}$ & $5.4 \times 10^{12} / \mathrm{L}$ & $5.61 \times 10^{12} / \mathrm{L}$ & $4-6 \times 10^{12} / \mathrm{L}$ \\
\hline Hemoglobin & $10.1 \mathrm{~g} / \mathrm{dl}$ & $10.4 \mathrm{~g} / \mathrm{dl}$ & $11.5-15.5 \mathrm{~g} / \mathrm{dl}$ \\
\hline $\mathrm{MCV}$ & $68.3 \mathrm{Fl} / \mathrm{rbc}$ & $68.8 \mathrm{Fl} / \mathrm{rbc}$ & $80-96 \mathrm{FL} / \mathrm{rbc}$ \\
\hline Platelets & $289 \times 10^{9} / \mathrm{L}$ & $304 \times 10^{9} / \mathrm{L}$ & $150-400 \times 10^{9} / \mathrm{L}$ \\
\hline Total Bilirubin & $6.9 \mathrm{mg} / \mathrm{dl}$ & - & $0.1-1.2 \mathrm{mg} / \mathrm{dl}$ \\
\hline Direct Bilirubin & $0.4 \mathrm{mg} / \mathrm{dl}$ & - & $0.3 \mathrm{mg} / \mathrm{dl}<$ \\
\hline ALT & $13 \mathrm{IU} / \mathrm{L}$ & - & $0-30 \mathrm{IU} / \mathrm{L}$ \\
\hline AST & $20 \mathrm{IU} / \mathrm{L}$ & - & $10-50 \mathrm{IU} / \mathrm{L}$ \\
\hline ALP & $198 \mathrm{IU} / \mathrm{L}$ & - & $30-150 \mathrm{IU} / \mathrm{L}$ \\
\hline Amylase & $42 \mathrm{IU} / \mathrm{L}$ & - & $100 \mathrm{IU} / \mathrm{L}<$ \\
\hline Lipase & $15 \mathrm{IU} / \mathrm{L}$ & - & $60 \mathrm{IU} / \mathrm{L}<$ \\
\hline BUN & $8 \mathrm{mg} / \mathrm{dl}$ & $12 \mathrm{mg} / \mathrm{dl}$ & $12-20 \mathrm{mg} / \mathrm{dl}$ \\
\hline Creatinine & $0.7 \mathrm{mg} / \mathrm{dl}$ & $0.7 \mathrm{mg} / \mathrm{dl}$ & $0.6-1.2 \mathrm{mg} / \mathrm{dl}$ \\
\hline $\mathrm{Na}$ & $138 \mathrm{mg} / \mathrm{dl}$ & $134 \mathrm{mg} / \mathrm{dl}$ & $131-146 \mathrm{mg} / \mathrm{dl}$ \\
\hline $\mathrm{K}$ & $3.9 \mathrm{mg} / \mathrm{dl}$ & $3.6 \mathrm{mg} / \mathrm{dl}$ & $3.6-5.1 \mathrm{mg} / \mathrm{dl}$ \\
\hline $\mathrm{BS}$ & $83 \mathrm{mg} / \mathrm{dl}$ & $125 \mathrm{mg} / \mathrm{dl}$ & $<200 \mathrm{mg} / \mathrm{dl}$ \\
\hline PT & $12.7 \mathrm{sec}$ & 12 & \\
\hline INR & 1.1 & 1 & \\
\hline PTT & $30 \mathrm{sec}$ & 46 & $25-45 \mathrm{sec}$ \\
\hline
\end{tabular}

WBC: White Blood Cell, RBC: Red Blood Cell, MCV: Mean Corpuscular Volume, ALT: Alanine transaminase, AST: Aspartate transaminase, ALP: Alkaline Phosphatase, BUN: Blood Urea Nitrogen, PT: Prothrombin Time, PTT: Partial Thromboplastin time, INR: International Normalized Ratio 


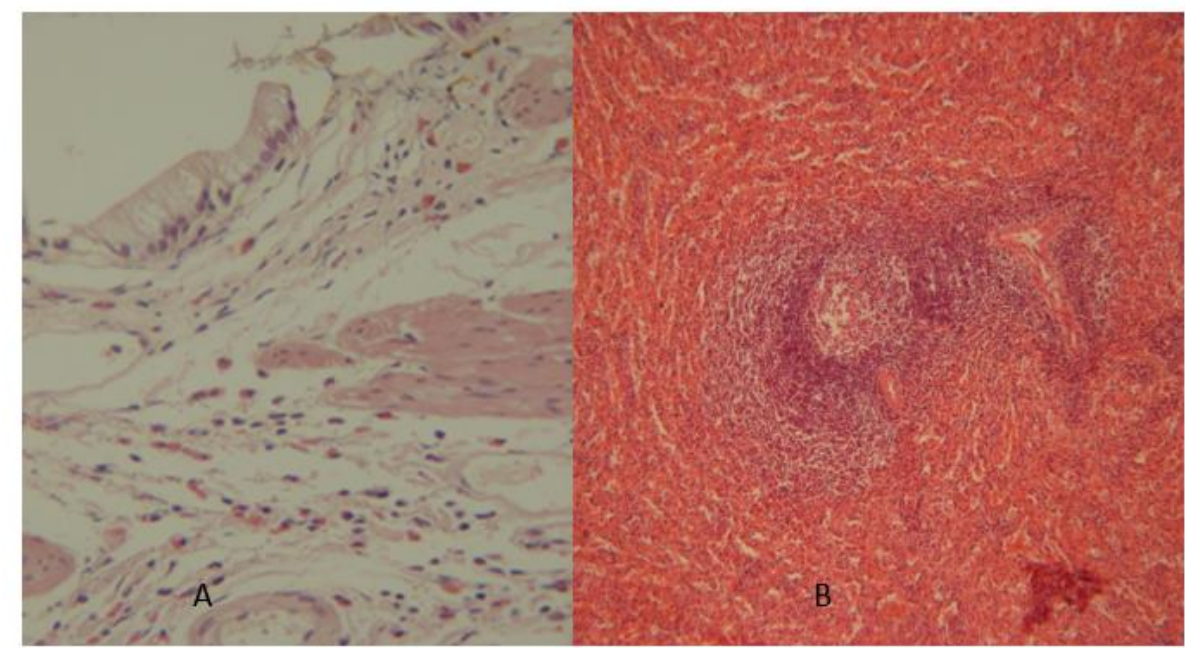

Figure 1. B. Congestive splenic tissue (40x, H\&E stain) A. Eosinophilic cholecystitis (40x, H\&E stain)

\section{Discussion}

$\mathrm{EC}$ is an infrequent inflammatory condition of the gallbladder with a prevalence of $0.25 \%$ to $6.4 \%$ in all patients with cholecystitis $(\mathbf{5 , 8})$. The mean age of presentation occurs at about 40 years with no detected incidences in a specific gender or race $[9,10]$.

Clinically, EC cannot be distinguished from causes of cholecystitis and its diagnosis is based on classical symptoms of cholecystitis such as right upper quadrant (RUQ) pain and Murphy's sign (patient firmly places his or her hand at the costal margin in the RUQ and with deep inspiration will have extreme pain). Thus, the diagnosis is based on the histopathological findings of a cholecystectomy specimen.

Although no definitive etiology can be drawn for EC, it has been reported as idiopathic or in combination with autoimmune reactions, allergies, hypereosinophilic syndromes (HES), parasites (Hepatic echinococcosis), eosinophilic gastroenteritis, and hypersensitivity to drugs and herbal medicines $(\mathbf{5 , 6 , 1 1})$. In histopathology, when eosinophils account for $90 \%$ of inflammatory cells, it will be called eosinophilic cholecystitis but when the infiltrate consists of $50 \%$ to $75 \%$ eosinophils along with other inflammatory cells in the gallbladder wall, they are classified as Lymphoeosinophilic cholecystitis $(\mathbf{1 2}, 13)$.

Calculi are associated in $40 \%$ of cases of both eosinophilic and Lymphoeosinophilic varieties (14). EC prevalence in acalculous cholecystitis is three times more than that of cholelithiasis (2). In literature acalculous cholecystitis is reported in obstructive jaundice which is more common in men (12).

In a conducted study of 7,494 patients who underwent cholecystectomies in a 14 year period, the prevalence of
EC was $0.16 \%$, which is 1 case for every 625 cholecystectomies performed. All of them were idiopathic and had concomitant gallstones (15). After evaluating clinical examinations, history and investigations of this case report, the only noteworthy causes of EC were an allergic history, favism, and cephalosporin medications during hospital stay, which could be considered as predisposing etiologies.

The definitive treatment of EC is surgical cholecystectomy; however, medical management such as steroids may be useful in EC associated patients of eosinophilic gastroenteritis or HES, depending on the severity of disease $(\mathbf{1 2}, \mathbf{1 6})$. In our patient, cholecystectomy led to full recovery. The patient was also periodically monitored at the outpatient department and passed an uneventful postop course.

\section{Conclusion}

EC is an infrequent condition with unknown etiology. Gastroenterologists, pathologists, and surgeons need to consider EV because if a causative factor is discovered, follow up and treatment may lead to diagnosis of an important disease. The diagnosis of eosinophilic cholecystitis is based on histopathologic findings because it has no specific clinical or laboratory feature and cholecystectomy is the definitive treatment. As seen in our case, EC was associated with favism and thalassemia intermediate which in accordance to the findings of medical texts, no such case has been previously reported.

\section{Acknowledgements}

The authors would like to express their gratitude to the Clinical Research and Development Unit of Ayatollah Rouhani Hospital in Babol, Iran. 


\section{Conflict of Interest}

Authors declared no conflict of interests.

\section{References}

1. Albot G, Poileux H, Olivier C, Libaude H, Cascarigny P. Les cholecystites a eosinophils. Presse Med. 1949; 39: 558-9.

2. Del-Moral-Martinez M, Barrientos-Delgado A, Crespo-Lora V, Cervilla-Sáez-de-Tejada ME, Salmerón-Escobar J. Eosinophilic cholecystitis: an infrequent cause of acute cholecystitis. Rev Esp Enferm Dig. 2015; 107(1): 45-7.

3. Dattal DS, Kaushik R, Gulati A, Sharma V. Morphological spectrum of gall bladder lesions and their correlation with cholelithiasis. Int J Res Med Sci. 2017; 5(3): 840-6. [DOI:10.18203/2320-6012.ijrms20170622]

4. Choudhury M, Pujani M, Katiyar Y, Jyotsna PL, Rautela A. Idiopathic eosinophilic cholecystitis with cholelithiasis: a report of two cases. Turk J Pathol. 2014; 30(2): 142-4. [DOI:10.5146/tjpath.2014.01235] [PMID]

5. Lai C-H, Chin C, ChungH-C, Liu H, Hwang J-C, Lin H-H. Clonorchiasis-associated perforated eosinophilic cholecystitis. Am J Trop Med Hygiene. 2007; 76(2): 396-8. [DOI:10.4269/ajtmh.2007.76.396]

6. Hepburn A, Coady A, Livingstone J, Pandit N. Eosinophilic cholecystitis as a possible late manifestation of the eosinophilia-myalgia syndrome. Clin Rheumatol. 2000; 19(6): 470-2. [DOI:10.1007/s 100670070008] [PMID]

7. Khan S, Hassan MJ, JairaJPuri ZS, Jetley S, Husain M. Clinicopathological study of eosinophilic cholecystitis: five year single institution experience. J Clin Diag Res. 2017; 11(8): EC20-23. [DOI:10.7860/JCDR/2017/27886.10427] [PMID] [PMCID]

8. Mohan H, Punia R, Dhawan S, Ahal S, Sekhon M. Morphological spectrum of gallstone disease in 1100 cholecystectomies in North India. Indian J Surg. 2005; 67(3): 140.

9. Shakov R, Simoni G, Villacin A, Baddoura W. Eosinophilic cholecystitis, with a review of the literature. Ann Clin Lab Sci. 2007; 37(2): 182-5.

10. Felman RH, Sutherland DB, Conklin JL, Mitros FA. Eosinophilic cholecystitis, appendiceal inflammation, pericarditis, and cephalosporin-associated eosinophilia. Digest $\begin{array}{llll}\text { Disease } & \text { Sci. } & \text { 1994; } & \text { 39): }\end{array}$ [DOI:10.1007/BF02090217] [PMID]

11. Adusumilli PS, Lee B, Parekh K, Farrelly PA. Acalculous eosinophilic cholecystitis from herbal medicine: a review of adverse effects of herbal medicine in surgical patients. Surgery. 2002; 131(3): 352-6. [DOI:10.1067/msy.2002.121540] [PMID]

12. Punia R, Arya S, Jain P, Bal A, Mohan H. Eosinophilic and lympho-eosinophilic cholecystitis. Indian J Gastoenterol. 2003; 22(4): 153-4.

13. Hellstrom H. Eosinophilic and lymphoeosinophilic cholecystitis. Am J Surg Pathol. 1994; 18(2): 215-6.

14. Dabbs DJ. Eosinophilic and lymphoeosinophilic cholecystitis. Am J Surg Pathol. 1993; 17(5): 497-501. [DOI:10.1097/00000478-199305000-00009] [PMID]

15. Gutiérrez-Moreno L, Trejo-Avila M, Díaz-Flores A, DávilaZenteno M, Montoya-Fuentes I, Cárdenas-Lailson L. Eosinophilic cholecystitis: a retrospective study spanning a fourteen-year period. Rev Gastroenterol Mex. 2018; 83: 4059. [DOI:10.1016/j.romxen.2018.09.002]

16. Tajima K, Katagiri T. Deposits of eosinophil granule proteins in eosinophilic cholecystitis and eosinophilic colitis associated with hypereosinophilic syndrome. Digest Disease Sci. 1996; 41(2): 282-8 [DOI:10.1007/BF02093816] [PMID]

\title{
How to Cite This Article:
}

Ranaee R, Khosravi M, Vosough Z. A Rare Case of Eosinophilic Cholecystitis Presenting in a Patient with Thalassemia Intermedia; a Case Report. J Adv Med Biomed Res. 2019; 27 (121) :54-57

\author{
Download citation: \\ $\underline{\text { BibTeX }} \underline{\text { RIS }} \underline{\text { EndNote }} \underline{\text { Medlars }} \underline{\text { ProCite }} \underline{\text { Reference Manager }} \underline{\text { RefWorks }}$

\section{Send citation to:}

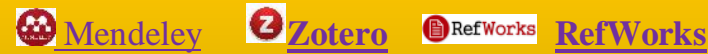

